\title{
Estradiol Protects Neuropeptide Y/ Agouti-Related Peptide Neurons against Insulin Resistance in Females
}

\author{
Jian Qiu ${ }^{a}$ Martha A. Bosch ${ }^{a}$ Chungang Zhang ${ }^{a}$ Oline K. Rønnekleiv ${ }^{a}$ b \\ Martin J. Kelly ${ }^{a, b}$ \\ a Department of Chemical Physiology and Biochemistry, Oregon Health and Science University, Portland, OR, USA; \\ ${ }^{b}$ Division of Neuroscience, National Primate Research Center, Oregon Health and Science University, Beaverton, OR, \\ USA
}

\section{Keywords}

Estradiol · Hypothalamus · Neuropeptide Y/agouti-related peptide - Obesity $\cdot$ Insulin resistance

\begin{abstract}
When it comes to obesity, men exhibit a higher incidence of metabolic syndrome than women in early adult life, but this sex advantage wanes in postmenopausal women. A key diagnostic of the metabolic syndrome is insulin resistance in both peripheral tissues and brain, especially in the hypothalamus. Since the anorexigenic hormone $17 \beta$-estradiol $\left(E_{2}\right)$ regulates food intake in part by inhibiting the excitability of the hypothalamic neuropeptide Y/agouti-related peptide (NPY/AgRP) neurons, we hypothesized that $\mathrm{E}_{2}$ would protect against insulin resistance in NPY/AgRP neurons with diet-induced obesity (DIO). Therefore, we did whole-cell recordings and single cell quantitative polymerase chain reaction in arcuate NPYGFP neurons from both female and male mice to test the efficacy of insulin with DIO. The resting membrane potential and input resistance of NPY/AgRP neurons were significantly increased in DIO versus control-diet fed males. Most notably, the efficacy of insulin to activate $K_{\text {ATP }}$ channels in NPY/AgRP neurons was significantly attenuated, although
\end{abstract}

the $K_{\text {ATP }}$ channel opener diazoxide was fully effective in NPY/ AgRP neurons from DIO males, indicating that the $K_{A T P}$ channels were expressed and functional. In contrast, insulin was fully efficacious to activate $\mathrm{K}_{\text {ATP }}$ channels in DIO females, and the response was reversed by the $\mathrm{K}_{\text {ATP }}$ channel blocker tolbutamide. However, the ability of insulin to activate $\mathrm{K}_{\text {ATP }}$ channels was abrogated with ovariectomy but fully restored with $E_{2}$ replacement. Insulin resistance in obese males was likely mediated by an increase in suppressor of cytokine signaling-3 (SOCS-3), protein tyrosine phosphatase B (PTP1B) and T-cell protein tyrosine phosphatase (TCPTP) activity, since the expression of all 3 mRNAs were upregulated in the obese males but not in females. As proof of principle, preincubation of hypothalamic slices from DIO males with the PTP1B/TCPTP inhibitor CX08005 completely rescued the effects of insulin. Therefore, $E_{2}$ protects NPY/AgRP neurons in females against insulin resistance through, at least in part, attenuating phosphatase activity. The neuroprotective effects of $E_{2}$ may explain sex differences in the expression of metabolic syndrome that disappears with the loss of $E_{2}$ in aging. (c) 2019 S. Karger AG, Basel

\section{KARGER}

(c) 2019 S. Karger AG, Basel

E-Mail karger@karger.com

www.karger.com/nen
Martin J. Kelly and Jian Qiu

Department of Chemical Physiology and Biochemistry

Oregon Health and Science University

3181 Southwest Sam Jackson Park Road, Portland, OR 97239 (USA)

E-Mail kellym@ohsu.edu and qiuj@ ohsu.edu 


\section{Introduction}

At the center of the regulation of energy homeostasis, and hence the central feedback of insulin, are the anorexigenic proopiomelanocortin (POMC) and orexigenic neuropeptide Y/agouti-related peptide (NPY/AgRP) neurons in the hypothalamic arcuate nucleus. These 2 neuronal populations are adjacent to the median eminence and hence are strategically located for monitoring hormones and nutrients and transmitting homeostatic signals to other areas [1]. Also, the NPY/AgRP neurons in particular are involved in integrating anticipatory sensory cues to generate appropriate feeding behavior [2]. Hence, optogenetic and pharmacogenetic stimulation of NPY/AgRP neurons rapidly increases food consumption $[3,4]$, whereas stimulation of POMC neurons attenuates food intake $[3,5]$. NPY/AgRP and POMC neurons are also the major CNS targets of insulin and leptin actions [6-10].

In an ex vivo hypothalamic slice preparation, insulin hyperpolarizes NPY/AgRP neurons via activation of $\mathrm{K}_{\mathrm{ATP}}$ channels, whereas it depolarizes POMC neurons via the activation of canonical transient receptor potential 5 (TRPC5) channels, activities that are consistent with the anorexigenic effects of insulin $[9,11]$. Insulin infused into the third ventricle (icv) decreases food intake in guinea pigs [9], mice [12, 13], and rats [14], which correlates with alterations in energy expenditure as exhibited by increases in $\mathrm{O}_{2}$ consumption, $\mathrm{CO}_{2}$ production, and metabolic heat production [9]. Also, icv insulin lowers blood glucose and suppresses hepatic glucose production (gluconeogenesis) [15]. Selective deletion of the insulin receptor in NPY/ AgRP neurons abrogates the ability of insulin to hyperpolarize and inhibit NPY/AgRP neurons and subsequently to lower hepatic glucose production [16]. Re-expression of the insulin receptor in NPY/AgRP neurons (and liver and pancreas) rescues the ability of insulin to control hepatic gluconeogenesis [17]. In addition, icv insulin reduces lipolysis and promotes lipogenesis in adipocytes through a decrease in sympathetic tone to white adipose tissue [9, 18]. Therefore, insulin signaling in the hypothalamus plays a major role in controlling hepatic glucose production.

Spanswick et al [19] first described the efficacy of insulin to hyperpolarize hypothalamic arcuate neurons in the rat, presumably only males, in a phosphoinositide 3-kinase (PI3K)-dependent manner [19]. In later studies using transgenic mice, it was shown that insulin specifically hyperpolarizes and inhibits the activity of both male and female NPY/AgRP neurons via a PI3K signaling pathway $[9,15,16,20,21]$. A more recent study found that selective deletion of the PI3K catalytic subunits p110 $\alpha$ and p110 $\beta$ in NPY/AgRP neurons of male mice eliminated the direct response to insulin in a slice preparation, and male mice exhibited weight gain, both an increase in fat and lean mass, on a regular chow diet [21]. PI3K generates phosphatidylinositol-3,4,5-triphosphate $\left(\mathrm{PIP}_{3}\right)$ from phosphatidylinositol 3,4-diphosphate $\left(\mathrm{PIP}_{2}\right)$, which stimulates phospholipase $\mathrm{C}$ and protein kinase $\mathrm{B}$ $[9,22-24]$, but it is the generation of $\mathrm{PIP}_{3}$ from $\mathrm{PIP}_{2}$ (removal of $\mathrm{PIP}_{2}$ from the membrane) that facilitates the $\mathrm{K}_{\mathrm{ATP}}$ channel opening [25].

A key "molecular switch" for controlling insulin receptor coupling to downstream effector systems in NPY/ AgRP neurons appears to be T-cell protein tyrosine phosphatase (TCPTP) activity. Fasting increases TCPTP expression in the mediobasal hypothalamus, whereas feeding represses TCPTP expression and promotes its degradation in male mice [26]. The postprandial decrease in TCPTP expression facilitates insulin receptor coupling to $\mathrm{K}_{\text {ATP }}$ channel activation, which inhibits neuronal activity [26] that ultimately affects whole-body glucose metabolism [27]. Moreover, selective deletion of the gene encoding TCPTP (Pnpt2) in NPY/AgRP neurons enhances insulin receptor signaling in NPY/AgRP neurons and consequently whole-body insulin sensitivity and glucose homeostasis in male mice [27], all of which are thought to be a direct consequence of the activation of $\mathrm{K}_{\mathrm{ATP}}$ channels in NPY/AgRP neurons $[10,16,28]$, which is the focus of the present study.

Insulin resistance is at the core of the metabolic syndrome and there is a sex difference in the expression of insulin resistance in adults. Neurons, similar to any cell, develop hyperinsulinemia-induced insulin resistance, which results in severe injury to the nervous system as seen in diabetic neuropathies [29]. Males exhibit a higher incidence of metabolic syndrome than women in early adult life, but this sex difference diminishes abruptly in hypo-estrogenic states [30, 31]. We discovered that POMC neurons from diet-induced obese male rodents were refractory to the actions of insulin, that is, the activation of canonical TRPC 5 channels was completely abrogated in obese males [11]. In contrast, insulin was fully efficacious in obese, reproductively active females. However, ovariectomy eliminated this protection, but $17 \beta$-estradiol $\left(\mathrm{E}_{2}\right)$ rescued the insulin response such that $\mathrm{E}_{2}$ replacement reinstated the insulin effects. Since NPY/ AgRP neurons are also a critical player and maybe even more important for control of hepatic glucose production [16], we hypothesized that $\mathrm{E}_{2}$ would protect against insulin resistance with diet-induced obesity (DIO) in NPY/ AgRP neurons, similar to POMC neurons. 


\section{Materials and Methods}

\section{Animals and Treatments}

All animal procedures described in this study were performed in accordance with institutional guidelines based on National Institutes of Health standards and approved by the Institutional Animal Care and Use Committee at Oregon Health and Science University.

\section{Mice}

For the electrophysiology and single-cell reverse transcription (RT) polymerase chain reaction (PCR) experiments, female and male $N p y^{\mathrm{GFP}}$ transgenic mice (provided by Dr. Brad Lowell, Harvard University, Cambridge, MA, USA) [32] were selectively bred in-house and maintained under controlled temperature $\left(25^{\circ} \mathrm{C}\right)$ and photoperiod conditions (lights on at 6 a.m. and off at 6 p.m.) with food and water ad libitum. We used a well-established, dietinduced obese mouse model to do cellular studies on NPY/AgRP neurons $[11,33,34] . N p y^{\mathrm{GFP}}$ mice were put on a high-fat diet (HFD; 45\% kcal from fat; Research Diets, New Brunswick, NJ, USA; D12451) starting at 3 weeks of age for 10 weeks to induce DIO. A control group of mice received normal grain-based chow (5L0D; Laboratory Diets, St. Louis, MO, USA). After at least 10 weeks on their diets ( $>13$ weeks of age), we prepared coronal slices from both groups of mice and did whole-cell voltage clamp recording from $N p y^{\mathrm{GFP}}$ (NPY/AgRP) neurons. In females, the estrous cycle was monitored daily based on vaginal cell cytology for at least 2 weeks before using the animals for electrophysiological experiments on proestrus. Other animals were ovariectomized (OVX) 1 week before the electrophysiology experiments and treated with $17 \beta-E_{2}$ benzoate $(E B)$ as previously described [11]. High circulating (proestrous) levels of $E_{2}$ were verified by the uterine weights $(>90 \mathrm{mg}$ ) at the time of hypothalamic slice preparation. Mice were housed individually, and body weight and food intake measurements were determined every 2 weeks. Food intake was determined as grams of diet consumed per day. The body composition was assessed with an EchoMRI Whole Body Composition Analyzer (Echo Medical Systems, Houston, TX, USA).

Glucose tolerance test. All mice were weaned at 3 weeks of age and given either a control diet or HFD as described above. Agematched control and DIO mice were fasted for 15-h and baseline glucose levels measured with the aid of an Accu-Check Advantage blood glucose meter (Roche) using blood collected from the tail vein. Mice were injected intraperitoneally with glucose $(1 \mathrm{mg} / \mathrm{g}$ lean mass as determined by MRI) in sterile PBS and blood glucose levels were measured 15, 30, 60, 90, and 120 min after injection. Glucose clearance (area under the curve) was calculated based on the glucose baseline levels at $0 \mathrm{~min}$ [32].

\section{Visualized Whole-Cell Patch Recording}

Whole-cell current clamp and voltage clamp recordings were made from $\mathrm{Npy}^{\mathrm{GFP}}$ neurons as previously described [35]. Coronal arcuate slices $(250 \mu \mathrm{m})$ were prepared from males and females as previously described [9]. Whole-cell patch recordings were made from $N p y^{\mathrm{GFP}}$ neurons using an Olympus BX51 W1 fixed-stage scope outfitted with epifluorescence and infrared differential interference contrast video microscopy. Patch pipettes (A-M Systems; $1.5-\mathrm{mm}$ outer diameter borosilicate glass; World Precision Instruments, Sarasota, FL, USA) were pulled on a Brown/Flaming puller (P-97; Sutter Instrument, Novato, CA, USA) and filled with the following internal solution: $128 \mathrm{mM}$ potassium gluconate, 10 $\mathrm{mM} \mathrm{NaCl}, 1 \mathrm{mM} \mathrm{MgCl} 2,11 \mathrm{~mm}$ EGTA, $10 \mathrm{~mm}$ HEPES, $3 \mathrm{~mm}$ adenosine triphosphate, and $0.25 \mathrm{mM}$ GTP adjusted to $\mathrm{pH} 7.3$ with $\mathrm{KOH}(295 \mathrm{mOsm})$. Pipette resistances ranged from 3.5 to $4 \mathrm{M} \Omega$. In whole-cell configuration, access resistance was $<20 \mathrm{M} \Omega$; the access resistance was $80 \%$ compensated. The input resistance was calculated by measuring the slope of the current-voltage (I-V) relationship curve between -70 and $-50 \mathrm{mV}$. Standard whole-cell patch recording procedures and pharmacological testing were performed as previously described [11]. Electrophysiological signals were digitized with a Digidata $1322 \mathrm{~A}$ (Axon Instruments), and the data were analyzed using p-Clamp software (Molecular Devices, Foster City, CA, USA). The liquid junction potential was corrected for all data analysis. I-V relationships of the insulin-generated currents were constructed by voltage ramps from -120 to $0 \mathrm{mV}$ from a holding potential of $-60 \mathrm{mV}$.

\section{Electrophysiological Solutions/Drugs}

A standard artificial cerebrospinal fluid (aCSF) was used [11]. All drugs were purchased from Calbiochem (San Diego, CA, USA) unless otherwise specified. Purified guinea pig insulin was purchased from Dr. Al Parlow (Harbor-UCLA Medical Center, Torrance, CA, USA) through the National Hormone and Peptide Program. The hyperpolarizing (outward current) responses to purified guinea pig insulin were exactly the same as what we have published for bovine (Sigma-Aldrich I-1882) and human recombinant (Sigma-Aldrich I-9278) insulin [9]. The responses to insulin were measured when the outward current reached a steady state in 2-15 $\mathrm{min}$, at which time the steady-state current was averaged over a $30 \mathrm{~s}$ time period. $17 \beta-\mathrm{E}_{2}$ benzoate (Sigma-Aldrich, St. Louis, MO, USA) was dissolved in ethanol before oil dissolution. Diazoxide (7-chloro-3-methyl-2H-1,2,4-benzo-thiadiazin 1,1-dioxide) and tolbutamide (Sigma-Aldrich) were dissolved in dimethylsulfoxide to a stock concentration of 300 and $100 \mathrm{mM}$ respectively. CX08005 (Sigma-Aldrich) was dissolved in dimethylsulfoxide to stock concentration of $20 \mathrm{mM}$. Aliquots of the stock solutions were stored as appropriate until needed.

\section{Cell Harvesting of Dispersed Npy ${ }^{G F P}$ Neurons and Quantitative} PCR

Intact males and females were fed grain-based control diet or high-fat diet as described above. After $\sim 10$ weeks on their respective diets, all the females were OVX and treated 5 days later with a low dose $(0.25 \mu \mathrm{g})$ of EB and a high dose $(1.50 \mu \mathrm{g})$ of EB on day 6 before using for experiments on day 7 [36]. Cell harvesting and quantitative PCR were conducted as previously described $[37,38]$. The arcuate nucleus was microdissected from basal hypothalamic coronal slices obtained from control, EB-treated OVX females and DIO, EB-treated OVX females and control and DIO male NpyGFP mice ( $n=5-6$ animals/group). The Npy ${ }^{G F P}$ dispersed cells were visualized, patched, and then harvested (10 cells/tube) as described previously [38]. The tissue was incubated in protease $(1 \mathrm{mg} / \mathrm{mL}$ in oxygenated aCSF for $15 \mathrm{~min}$ at $\left.37^{\circ} \mathrm{C}\right)$ or papain $(7 \mathrm{mg} / \mathrm{mL}$ in oxygenated aCSF for $40 \mathrm{~min}$ at $30^{\circ} \mathrm{C}$ ) and washed 4 times in low $\mathrm{Ca}^{2+}$ aCSF (and 2 times in aCSF). Gentle trituration with Pasteur pipettes of decreasing size were used to disperse the neurons onto a glass-bottom dish. We designed a glass-bottom $60-\mathrm{mm}$ dish to increase the surface area of the plate to allow greater segregation among cells. The healthy cells settled on the glass bottom dish after approximately 15-20 $\mathrm{min}$, at which time the aCSF was removed 
Table 1. Primer table

\begin{tabular}{|c|c|c|c|c|c|c|c|}
\hline \multirow{2}{*}{$\begin{array}{l}\text { Gene name } \\
\text { (encodes for) }\end{array}$} & \multirow[t]{2}{*}{ Accession, $n$} & \multirow{2}{*}{$\begin{array}{l}\text { Primer } \\
\text { location, nt }\end{array}$} & \multirow{2}{*}{$\begin{array}{l}\text { Product } \\
\text { length, bp }\end{array}$} & \multirow{2}{*}{$\begin{array}{l}\text { Annealing } \\
\text { temp., }{ }^{\circ} \mathrm{C}\end{array}$} & \multicolumn{3}{|c|}{ Efficiency } \\
\hline & & & & & slope & $r^{2}$ & $\%$ \\
\hline Socs3 (SOCS-3) & NM_007707 & $\begin{array}{l}1,913-1,932 \\
2,012-2,031\end{array}$ & 119 & 60 & -3.294 & 0.900 & 100 \\
\hline Ptpn2 (TCPTP) & NM_008977 & $\begin{array}{l}404-425 \\
488-509\end{array}$ & 106 & 60 & -3.305 & 0.958 & 100 \\
\hline Ptpn1 (PTP1B) & NM_011201 & $\begin{array}{l}837-856 \\
908-928\end{array}$ & 92 & 60 & -3.338 & 0.955 & 99 \\
\hline Pik3cb(Pi3Kp110ß) & NM_029094 & $\begin{array}{l}1,083-1,101 \\
1,149-1,167\end{array}$ & 85 & 60 & -3.419 & 0.970 & 96 \\
\hline $\operatorname{Scn} 2 b(\mathrm{Nav} \beta 2)$ & NM_001014761 & $\begin{array}{l}187-206 \\
272-291\end{array}$ & 105 & 60 & -3.356 & 0.988 & 99 \\
\hline Gapdh (GAPDH) & NM_008084 & $\begin{array}{l}689-706 \\
764-781\end{array}$ & 93 & 60 & -3.352 & 0.998 & 99 \\
\hline
\end{tabular}

SOCS3, suppressor of cytokine signaling-3; TCPTP, T-cell protein tyrosine phosphatase; PTP1B, protein tyrosine phosphatase; Scn2b, sodium channel $\beta 2$ subunit; Gapdh, glyceraldehyde 3-phosphate dehydrogenase.

and fresh aCSF was added to the plate. Throughout the dispersion and harvesting procedure, a constant flow $(2 \mathrm{~mL} / \mathrm{min})$ of oxygenated aCSF circulated into the plate, while the effluent circulated out using a peristaltic pump. The aCSF flow helped ensure that fresh, oxygenated media reached the cells and assisted in clearing out unhealthy cells and debris from the trituration. The cells harvested were those observed to be fully intact, with 1-3 processes and a smooth cell membrane. The cells were harvested using the XenoWorks Microinjector System (Sutter Instrument, Novato, CA, USA). This microinjector system provides negative pressure in the pipette, which, together with the fine and gentle control of the suction, allows each cell to be drawn into the pipette essentially without fluid. Cells were harvested as pools of 10 individual cells/tube.

Primers for the genes that encode for SOCS-3 (Socs3), TCPTP (Ptpn2), PTP1B (Ptpn1), sodium channel $\beta 2$ subunit (Nav $\beta 2$, Scn $2 b$ ), PI3K p110ß (Pi3kcb), and glyceraldehyde 3-phosphate dehydrogenase (Gapdh) were designed using Clone Manager software (Sci Ed Software, Denver, CO; Table 1). SOCS-3, Pi3K p110ß, $\mathrm{Nav} \beta 2$, and GAPDH primers have been previously published [11, 39]. Primers cross at least one intron-exon boundary and are optimized as previously described using the Power SYBR Green method [37]. Given that the Socs 3 gene only expresses one intron, which made it difficult to design efficient primers for PCR quantification, we designed a primer pair that did not cross exon-intron boundaries. Therefore, to avoid amplifying genomic DNA, the harvested neuronal pools used to measure Socs 3 were treated with DNase I (1 U/mg DNA; Invitrogen, Grand Island, NY, USA) at $10^{-3} \mathrm{U}$ for $10 \mathrm{~min}$ and heat denatured $\left(65^{\circ} \mathrm{C}\right)$ for $5 \mathrm{~min}$ prior to reverse transcription as previously described [11]. Controls included neuronal pools reacted without reverse transcriptase (RT), hypothalamic RNA reacted with RT and without RT, and water blanks. Primers for quantitative PCR were further tested for efficiency $\left(\mathrm{E}=10^{[-1 / \mathrm{m}]}-1\right.$, where $\mathrm{m}$ is the slope [40]), which varied from 96 to $100 \%$ (Table 1). Quantitative PCR was performed on a Quantstudio 7 Flex Real-Time PCR System (Life Technologies, Grand Island, NY, USA) using Power SYBR Green Master Mix (Life Technologies) according to established protocols [37]. The comparative cycle threshold $\left(2^{-\Delta \Delta \mathrm{CT}}\right)$ method was used to determine fold change from duplicate samples of $4 \mu \mathrm{L}$ for the target genes Socs3, Ptpn2, Ptpn1, Scn2b, Pi3kcb, and $2 \mu \mathrm{L}$ for the reference gene Gapdh [41].

To determine the relative expression levels of target genes in $N p y^{\mathrm{GFP}}$ neurons obtained from control grain-fed animals compared with DIO animals, 4 pools ( 10 cells/pool) from each of 5-6 animals were used. The mean $\Delta \mathrm{CT}$ from the grain-fed samples was used as the calibrator. Data were expressed as the change in gene expression normalized to the reference gene Gapdh and relative to the calibrator, and the mean and standard error of the mean were calculated and used for statistical analysis [37].

\section{Results}

\section{NPY/AgRP Neurons in Obese Males Are Insulin Resistant}

The average food intake (kcal/day) between control diet and HFD male or female Npy ${ }^{\mathrm{GFP}}$ mice was not significantly different (unpaired $t$ test for males, $t_{[18]}=1.691$; $p=0.1081$; Controls: $17.8 \pm 1.2 \mathrm{kcal} /$ day, $n=8$ vs. DIO males: $15.7 \pm 0.5 \mathrm{kcal} / \mathrm{day}, n=12$; unpaired $t$ test for females, $t_{[20]}=0.0084 ; p=0.9934$; Controls: $14.4 \pm 0.8 \mathrm{kcal} /$ day, $n=9$ vs. DIO females: $14.4 \pm 0.3 \mathrm{kcal} / \mathrm{day}, n=13$ ). However, the total body weight of DIO male and female 


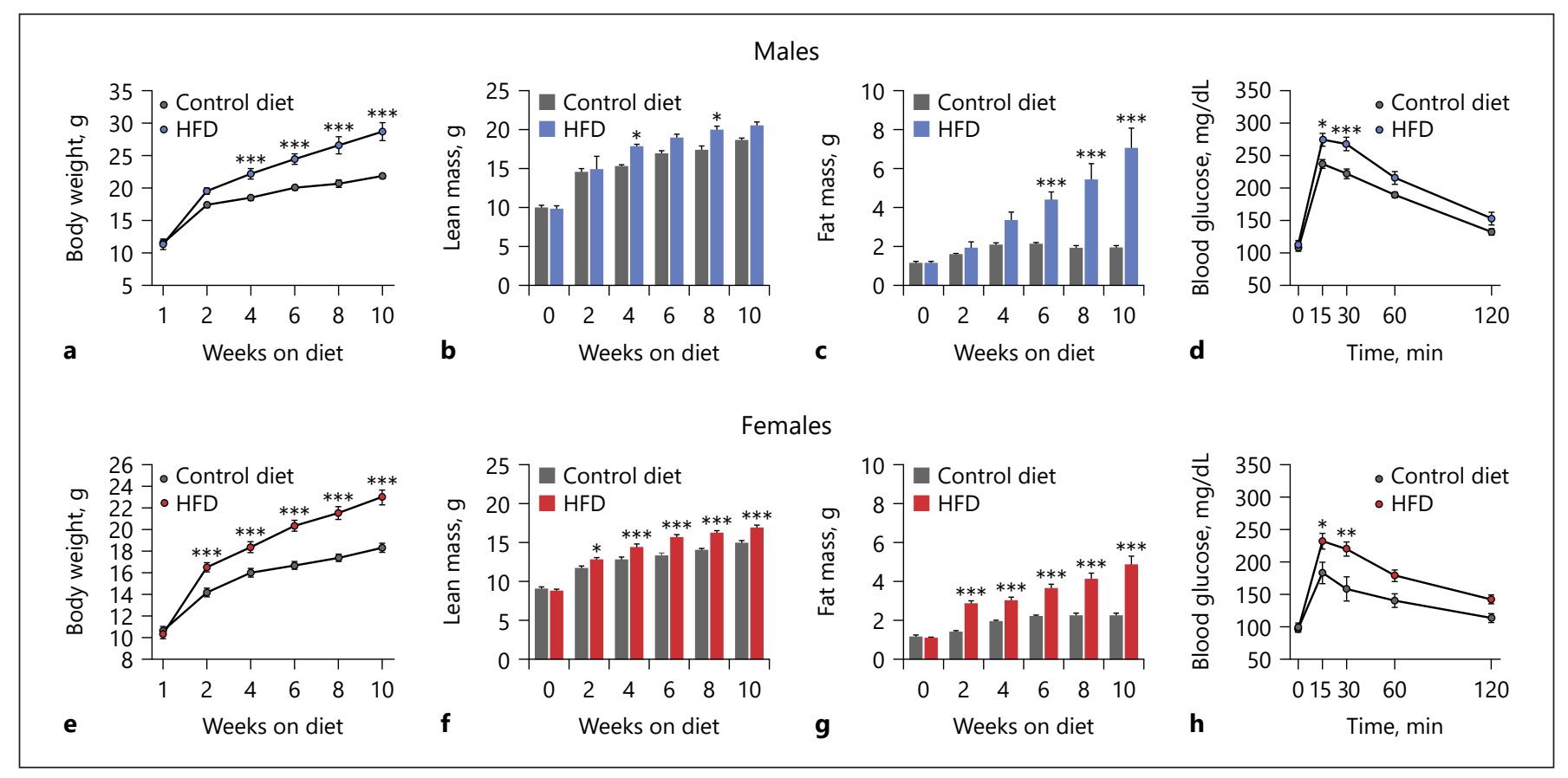

Fig. 1. Male and female mice on high fat diet become obese and glucose intolerant. a-c Male $N p y^{G F P}$ mice were maintained on a high fat diet (45\% fat) or a control, grain-based diet for 10 weeks. The high fat diet caused a significant weight gain and DIO (a) over the 10 weeks period, which was significantly different from controls by week 4 (two-way ANOVA: main effect of treatment $\left(F_{[1,42]}=66.10, p<0.001\right)$, main effect of time $\left(F_{[5,42]}=75.43, p<\right.$ $0.001)$ and interaction $\left(F_{[5,42]}=5.151, p=0.001\right)$; Control $n=4$, DIO mice $n=5$; post hoc Bonferroni test). b, $\mathbf{c}$ Lean mass and total body fat were measured by EchoMRI. Lean mass (b) does not include bone and fluids within organs. The difference in fat content (c) between the groups became significantly different at 6 weeks. Two-way ANOVA for $\mathbf{b}$ : main effect of treatment $\left(F_{[1,42]}=12.36\right.$, $p=0.001)$, main effect of time $\left(F_{[5,42]}=44.13, p<0.001\right)$ and interaction $\left(F_{[5,42]}=1.191, p=0.3299\right)$; Control mice $\mathrm{n}=4$; DIO mice $n=5$; post hoc Bonferroni test; Two-way ANOVA for c: main effect of treatment $F_{(1,42)}=48.82, p<0.001$, main effect of time $F_{(5,42)}=11.72, p<0.001$, and interaction $\left(F_{[5,42]}=7.359, p<0.001\right)$. Control mice $n=4$, DIO mice $n=5$; post hoc Bonferroni tests). e-g Female $N p y^{G F P}$ mice were maintained on a high fat diet $(45 \%$ fat) or a control, grain-based diet for 10 weeks. The high fat diet caused a significant weight gain and DIO (e) over the 10 weeks period, which was significantly different than controls by week 2 (two-way ANOVA: main effect of treatment $\left(F_{[1,108]}=95.54, p<\right.$

$N p y^{G F P}$ mice was significantly greater than control diet mice by week 4 or 2 respectively (Fig. 1a, e). The average lean mass of DIO male and female $N p y^{G F P}$ mice was significantly greater than mice fed a control diet by week 4 (DIO males: $17.8 \pm 0.4 \mathrm{~g}$; control males: $15.2 \pm 0.3 \mathrm{~g}$; Fig. 1b) or week 2 (DIO females: $12.8 \pm 0.3 \mathrm{~g}$; control females: $11.7 \pm 0.3 \mathrm{~g}$; Fig. 1f). More importantly, the average
$0.001)$, main effect of time $\left(F_{[5,108]}=108.7, p<0.001\right)$ and interaction $\left(F_{[5,108]}=6.819, p<0.001\right)$; Control-diet $n=8$, DIO mice $n=$ 12; post hoc Bonferroni test). The lean (f) and fat (g) content between groups became significantly different at 2 weeks (two-way ANOVA for the lean mass $(\mathbf{f})$ : main effect of treatment $\left(F_{[1,108]}=\right.$ $51.31, p<0.001)$, main effect of time $\left(F_{[5,108]}=97.79, p<0.001\right)$ and interaction $\left(F_{[5,108]}=3.606, p=0.005\right)$, Control mice $n=8$; DIO mice $n=12$; Two-way ANOVA for fat content mass $(\mathbf{g})$ : main effect of treatment $\left(F_{[1,108]}=93.75, p<0.001\right)$, main effect of time $\left(F_{[5,108]}=23.74, p<0.001\right)$ and interaction $\left(F_{[5,108]}=6.426, p<\right.$ 0.001 ), Control mice $n=8$; DIO mice $n=12$; post hoc Bonferroni tests). ${ }^{*} p<0.05$; ${ }^{* * *} p<0.005$. Both (d) DIO male and (h) female $N P Y^{\mathrm{GFP}}$ mice at 10 weeks exhibited glucose intolerance versus their age-matched controls (fed grain-based diet). The GTTs showed significantly higher peak blood glucose levels $15 \mathrm{~min}$ after i.p. glucose (see "Materials and Methods") and a delayed clearance. Twoway ANOVA for $(\mathbf{d})$ : main effect of treatment $\left(F_{[1,95]}=25.48, p<\right.$ $0.0001)$, main effect of time $\left(F_{[4,95]}=114.5, p<0.0001\right)$ and interaction $\left(F_{[4,95]}=1.862, p=0.1234\right)$; control, $n=9$, HFD, $n=12$; post hoc Bonferroni test, ${ }^{*} p<0.05$; ${ }^{* * *} p<0.005$. Two-way ANOVA for (h): main effect of treatment $\left(F_{[1,85]}=20.76, p<0.0001\right)$, main effect of time $\left(\mathrm{F}_{[4,85]}=25.55, p<0.0001\right)$ and interaction $\left(F_{[4,85]}=\right.$ $1.775, p=0.1414)$; control, $n=8$, HFD, $n=12$; post hoc Bonferroni test, ${ }^{*} p<0.05$; ${ }^{* *} p<0.01$. HFD, high-fat diet. fat mass of DIO male $N p y^{G F P}$ mice was significantly greater than control diet mice by week 6 (DIO males: $4.4 \pm 0.4$ g; control males: $2.1 \pm 0.1$ g; Fig. 1c), whereas the average fat mass of DIO female $N p y^{G F P}$ mice was significantly greater than control diet mice by week 2 (DIO females: $2.8 \pm 0.2 \mathrm{~g}$; control females: $1.4 \pm 0.1 \mathrm{~g}$; Fig. $1 \mathrm{~g})$. After 10 weeks on their diets (13 weeks of age), the fat mass data 
Fig. 2. NPY/AgRP neurons from DIO males are insulin resistant. In voltage clamp, insulin $(20 \mathrm{nM})$ induced an outward current in NPY/AgRP neurons from male mice on a control diet, which was reversed by the $\mathrm{K}_{\mathrm{ATP}}$ channel blocker tolbutamide (100 $\mu \mathrm{M} ; \mathbf{a})$, but had no effect in NPY/ AgRP neurons from DIO male mice (c). $\mathrm{V}_{\text {hold }}=-60 \mathrm{mV}$. b The I-V relationship for the insulin-induced current from a control diet-fed mouse was obtained from the recording in a showing an outward current, which had a reversal potential close to $\mathrm{E}_{\mathrm{K}+}$ $(-87.7 \pm 4.3 \mathrm{mV}, n=3)$. d The I-V relationship for the insulin-induced current from a DIO mouse obtained from the recording in c showed no evidence of an increased $\mathrm{K}^{+}$ conductance with bath perfusion of insulin. e $K_{A T P}$ channel opener diazoxide (300 $\mu \mathrm{M})$ induced an outward $\mathrm{K}^{+}$current in NPY/AgRP neurons from DIO males that did not respond to insulin. $f$ The $\mathrm{I}-\mathrm{V}$ relationship obtained from the recording in e showing an outward current which had a reversal potential close to $\mathrm{E}_{\mathrm{K}+}(-90 \pm 2.6$ $\mathrm{mV}, n=6) . \mathbf{g}, \mathbf{h}$ Bar graphs summarizing the insulin- (g) and diazoxide-induced (h) outward currents in NPY/AgRP neurons from control diet, and DIO male mice. Data points represent the mean \pm SEM. Unpaired $t$ test for G: $t_{(26)}=3.989, p=$ 0.0005 ; *** $p<0.005$ versus control; unpaired $t$ test for $\mathrm{H}: t_{(11)}=0.4438, p=0.6658$. Cell numbers are indicated. DIO, diet-induced obesity.

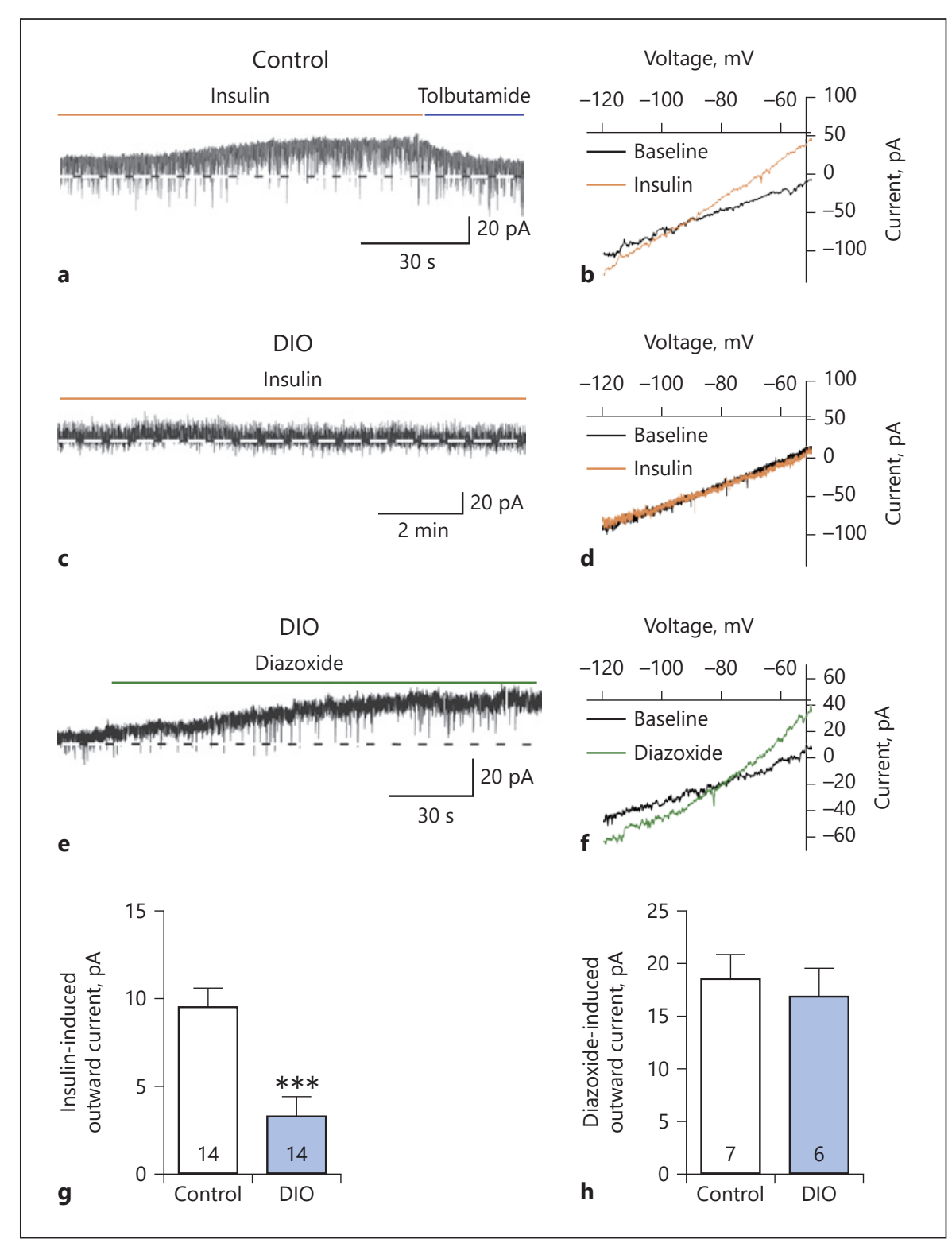

presented as percentage of total body weight were significantly different between controls and DIO groups (controls: $8.7 \pm 0.6 \%, n=4$ vs. DIO males: $24.1 \pm 2.6 \%, n=5$, unpaired $t$ test, $t_{[7]}=1.158 ; p=0.0015$; controls: $12.0 \pm$ $0.9 \%, n=8$ vs. DIO females: $20.7 \pm 1.6 \%, n=12$, unpaired $t$ test, $t_{[18]}=4.231 ; p=0.0005$ ). . Moreover, both DIO males and females had a significantly different glucose clearance rate than their age-matched controls (Fig. 1d, h: area under the curve: DIO males: $25,265 \pm 984 \mathrm{mg} / \mathrm{dL} \times \mathrm{min}$, $n=12$ vs. control males: $21,870 \pm 365 \mathrm{mg} / \mathrm{dL} \times \mathrm{min}, n=$ $9, t_{[19]}=2.861, p=0.0100$; DIO females: $21,425 \pm 873 \mathrm{mg} /$ $\mathrm{dL} \times \min , n=12$ vs. control females: $16,730 \pm 1,387 \mathrm{mg} /$ $\left.\mathrm{dL} \times \min , n=8, t_{[18]}=3.023, p=0.0073\right)$.
Subsequently, we prepared hypothalamic slices from the DIO N $p y^{G F P}$ mice after 10 weeks on their diets and did whole-cell current and voltage clamp recordings from NPY/AgRP neurons in male mice using established protocols to determine the efficacy of insulin to hyperpolarize NPY neurons [9]. DIO male mice were $~ 34 \%$ heavier than controls at the time that they were euthanized for electrophysiology studies $(34.1 \pm 3.0 \mathrm{~g}, n=7$ vs. $25.5 \pm 0.5$ g, $n=14$, respectively, unpaired two-tailed $t$ test, $t_{[19]}=$ 4.016, $p=0.0007$ ) and had deposited $~ 4.6$ times as much total body fat. Consistent with the EchoMRI data, the perigonadal fat pad in DIO males was significantly heavier as compared with the control diet males $(1,573 \pm 267$ 
mg, $n=6$ vs. $339 \pm 24 \mathrm{mg}, n=14$, unpaired $t$ test, $t_{[18]}=$ $7.163, p<0.0001)$. For the male NPY/AgRP neurons, there was no difference in the membrane capacitance (DIO males: $14.7 \pm 0.7 \mathrm{pF}, n=14$ vs. controls: $14.8 \pm 1.0$ $\mathrm{pF}, n=14$; unpaired $t$ test, $\left.t_{[26]}=0.05851, p=0.9538\right)$, but there was a significant difference in the resting membrane potential (DIO males: $-75.6 \pm 2.1 \mathrm{mV}, n=38$ versus controls: $-63.6 \pm 1.9 \mathrm{mV}, n=36$; unpaired $t$ test, $t_{[72]}=2.243$, $p<0.0003$ ) and input resistance (DIO males: $2.0 \pm 0.2$ $\mathrm{G} \Omega, n=38$ versus controls: $1.5 \pm 0.1 \mathrm{G} \Omega, n=36$; unpaired $t$ test, $\left.t_{[72]}=2.343, p=0.0219\right)$ between the 2 groups, suggesting that the hyperpolarized resting membrane potential in DIO males could not have resulted from the opening of $\mathrm{K}^{+}$channels (including $\mathrm{K}_{\mathrm{ATP}}$ channels). As previously reported, we documented that NPY/AgRP neurons are hyperpolarized/inhibited by nanomolar concentrations of purified insulin through activation of $\mathrm{K}_{\mathrm{ATP}}$ channels that generates an outward current with a reversal of $-87.7 \pm 4.3 \mathrm{mV}(n=3)$ and an inwardly rectifying current-voltage plot (I/V) [9]. Therefore, we used voltageclamp recordings in both control and DIO animals to assess the response to insulin. We also generated I/Vs before and after insulin to verify the underlying conductance (Fig. 2b, d). As hypothesized, there was a significant difference in the steady-state response (outward current) to $20 \mathrm{nM}$ insulin (DIO males: $3.2 \pm 1.1 \mathrm{pA}, n=14$ vs. controls: $9.5 \pm 1.1 \mathrm{pA}, n=14$, unpaired $t$ test, $t_{[26]}=3.989$, $p=0.0005$; Fig. $2 \mathrm{a}-\mathrm{d}, \mathrm{g})$. Therefore, insulin appeared to be less efficacious in DIO males to activate $\mathrm{K}_{\mathrm{ATP}}$ channels.

Diazoxide has been shown to stimulate the opening of $\mathrm{K}_{\mathrm{ATP}}$ channels [42]. Therefore, we tested diazoxide in $\mathrm{NPY} / \mathrm{AgRP}$ neurons from DIO males to assess whether the $\mathrm{K}_{\mathrm{ATP}}$ channel conductance was diminished in the DIO state. Diazoxide $(300 \mu \mathrm{M})$ was able to fully activate the channels $(18.4 \pm 2.4 \mathrm{pA}, n=7$ in control males and $16.8 \pm 2.8 \mathrm{pA}, n=6$ in DIO males), and the I/V revealed that the outward current generated by diazoxide matched the effects of insulin in the controls with a reversal potential of $-90 \pm 2.6 \mathrm{mV}(n=6)$, indicative of activation of $\mathrm{K}_{\mathrm{ATP}}$ channels (Fig. 2e, f, h). Therefore, it appeared that the $\mathrm{K}_{\mathrm{ATP}}$ channels were not downregulated in DIO males, but instead, there was an uncoupling of InsRs from channel activation.

\section{NPY/AgRP Neurons in Obese, Proestrous Females \\ Maintain Insulin Sensitivity}

To test for a potential sex difference in the response to insulin with DIO after 10 weeks, we did whole-cell current and voltage clamp recordings from NPY/AgRP neurons from DIO female $N p y^{G F P}$ mice. The DIO female

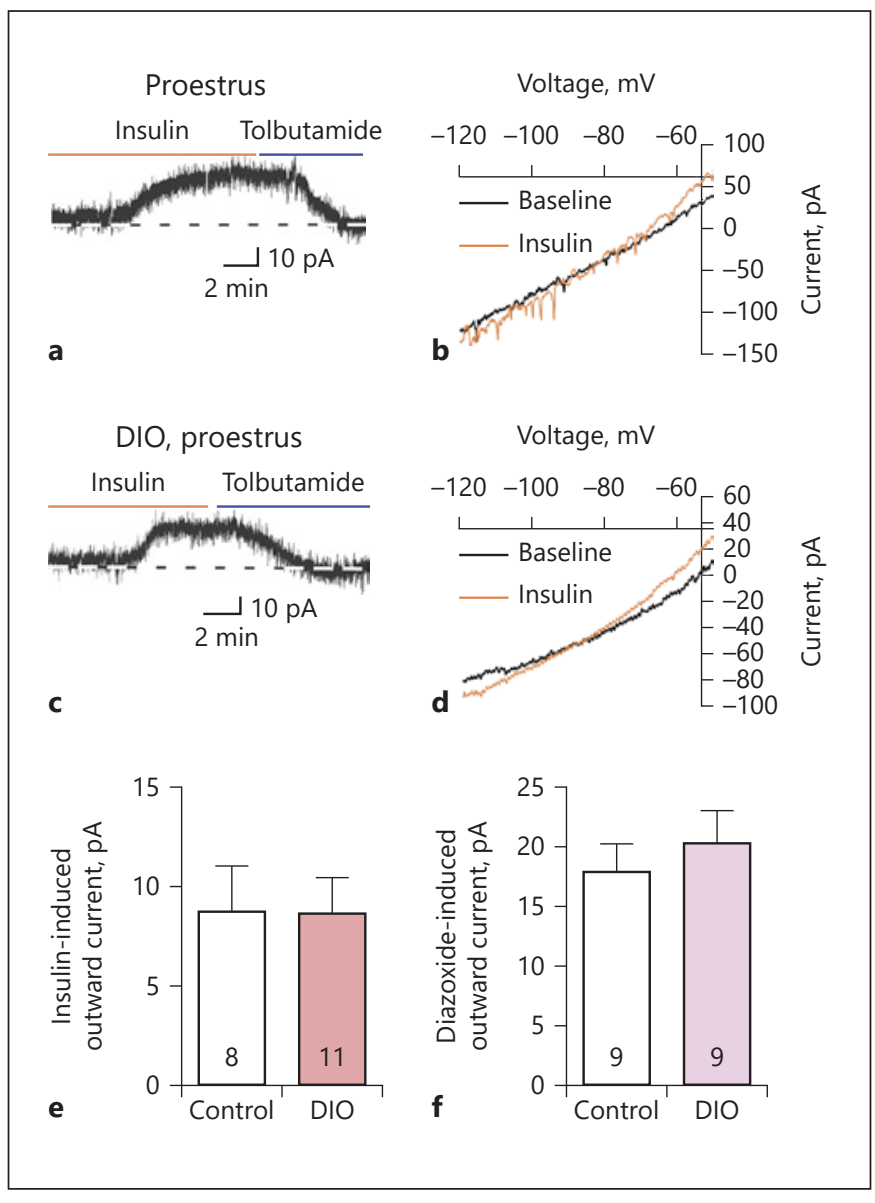

Fig. 3. NPY/AgRP neurons from DIO, proestrous females are protected against insulin resistance. a, c In voltage clamp, insulin (20 $\mathrm{nM}$ ) induced outward currents in NPY/AgRP neurons from proestrous female mice on a control diet (a) or DIO female mice (c), both of which were antagonized by tolbutamide. $\mathrm{V}_{\text {hold }}=-60 \mathrm{mV}$. Tolbutamide was equally efficacious to reverse the effects of insulin in control and DIO females (control: $14.6 \pm 3.2 \mathrm{pA}, n=4$; DIO females: $14.7 \pm 2.8 \mathrm{pA}, n=6$ ). $\mathbf{b}$ The I-V relationship for the insulin-induced current was obtained from the recording in $\mathbf{a}$, which showed an outward current that reversed at $\mathrm{E}_{\mathrm{K}+}(-88.6 \pm 1.9 \mathrm{mV}$, $n=7)$. $\mathbf{d}$ The I-V relationship for the insulin-induced current was obtained from a DIO mouse, which also showed an outward current that reversed at $\mathrm{E}_{\mathrm{K}+}(-87.0 \pm 3.1 \mathrm{mV}, n=4)$. e, $\mathbf{f}$ Bar graphs summarizing the insulin- (e) and diazoxide-induced (f) outward currents in NPY/AgRP neurons from control diet and DIO, proestrous female mice. Data points represent the mean \pm SEM. Unpaired $t$ test for $\mathrm{E}: t_{(17)}=0.02586, p=0.9797$; unpaired $t$ test for $\mathrm{F}$ : $t_{(16)}=0.5213, p=0.6658$. Cell numbers are indicated. DIO, dietinduced obesity.

mice were $\sim 12.5 \%$ heavier than controls at the time that they were euthanized for electrophysiology studies (24.3 $\pm 1.6 \mathrm{~g}, n=4$, vs. $21.6 \pm 0.5 \mathrm{~g}, n=10$, respectively, unpaired $t$ test, $\left.t_{[12]}=2.254, p=0.0437\right)$ and deposited $\sim 3$ times as 
Fig. 4. $\mathrm{E}_{2}$ replacement rescues insulin response in NPY/AgRP neurons from DIO, OVX females. a Insulin (20 nM) induced an outward current in voltage clamp in NPY/ AgRP neurons from control diet-fed, OVX female mice. The insulin responses were antagonized by $\mathrm{K}_{\mathrm{ATP}}$ channel blocker tolbutamide. $\mathrm{V}_{\text {hold }}=-60 \mathrm{mV}$. b In DIO, OVX females, the insulin response was abrogated in NPY/AgRP neurons. c However, the insulin response was rescued in DIO, OVX females with EB treatment. d Bar graphs summarizing the insulin-induced currents in normal diet and DIO, OVX and $\mathrm{E}_{2}$-treated female mice. Data points represent the mean \pm SEM (control diet, OVX females: $14.1 \pm 2.7 \mathrm{pA}, n=7$; DIO, OVX females: 1.4 $\pm 0.9 \mathrm{pA}, n=9$; DIO, EB-treated, OVX females: $9.6 \pm 2.2 \mathrm{pA}, n=12$; one-way ANOVA, effect of treatment, $F_{[2,25]}=8.531, p=$ 0.0015; Newman-Keuls' multiple-comparison post hoc test $\left.{ }^{* *} p<0.01\right)$. Cell numbers are indicated. OVX, ovariectomized; DIO, diet-induced obesity; EB, estradiol benzoate; ns, no significant difference.

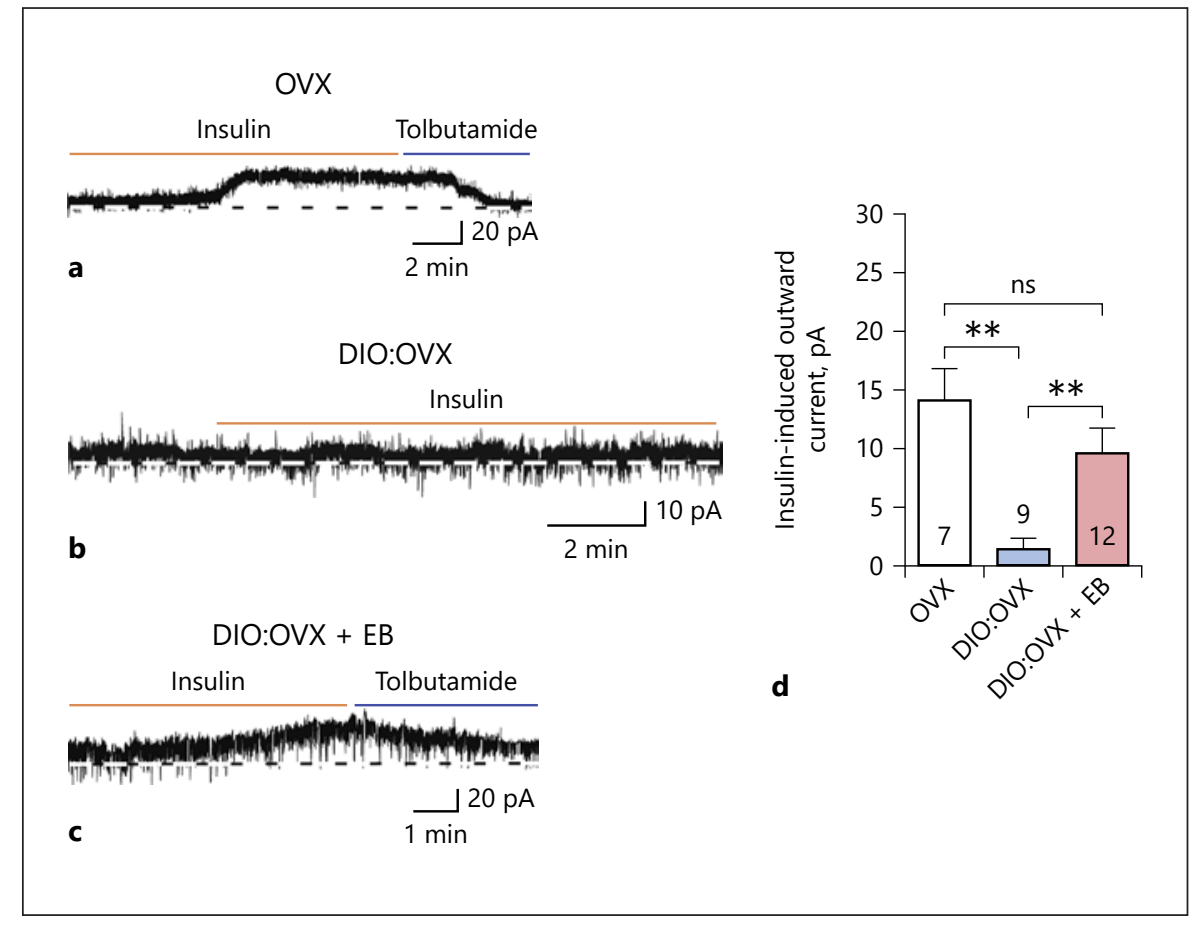

much total body fat. The uterine weights between control and DIO females at the proestrous stage were not significantly different (controls: $106.3 \pm 16.9 \mathrm{mg}, n=5 \mathrm{vs}$. DIO females: $100.3 \pm 6.1 \mathrm{mg}, n=4$, unpaired $t$ test, $t_{[7]}=0.3007$; $p=0.7724)$. Consistent with the EchoMRI data, the perigonadal fat pad was significantly heavier in the DIO females compared to that of the controls $(895 \pm 137 \mathrm{mg}$, $n=4$ vs. $171 \pm 25 \mathrm{mg}, n=6$, unpaired $t$ test, $t_{[8]}=6.396$, $p=0.0002)$. In contrast to males, there was no difference in the resting membrane potential (DIO females: $-65.1 \pm 1.5$ $\mathrm{mV}, n=13$ vs. controls: $-64.2 \pm 1.3 \mathrm{mV}, n=23$, unpaired $t$ test, $t_{[34]}=0.4120, p=0.6829$ ) or input resistance (DIO females: $1.4 \pm 0.1 \mathrm{G} \Omega, n=41$ vs. controls: $1.2 \pm 0.1 \mathrm{G} \Omega$, $n=24$, unpaired $t$ test, $t_{[63]}=1.340, p=0.1850$ ) or membrane capacitance (DIO females: $13.9 \pm 0.6 \mathrm{pF}, n=41 \mathrm{vs}$. controls: $14.9 \pm 0.6 \mathrm{pF}, n=24$, unpaired $t$ test, $t_{[63]}=1.158$; $p=0.2514$ ) between the 2 groups. Again, we used sensitive voltage-clamp recordings to access the effects of insulin. Also in contrast to the males, the steady-state response (outward current) to $20 \mathrm{nM}$ insulin was not attenuated in DIO females (DIO females: $8.6 \pm 1.8 \mathrm{pA}, n=$ 11 , controls: $8.7 \pm 2.3 \mathrm{pA}, n=8$; Fig. $3 \mathrm{a}$, c, summarized in Fig. 3e). The insulin-induced outward current reversed at $-88.6 \pm 1.9 \mathrm{mV}(n=7)$ in controls and $-87.0 \pm 3.1 \mathrm{mV}$ $(n=4)$ in DIO females (Fig. 3b, d), and was antagonized by the $\mathrm{K}_{\mathrm{ATP}}$ channel blocker tolbutamide (Fig. 3a, c). The diazoxide-induced outward current was also not different between control and DIO females (summarized in Fig. 3f). Therefore, we were confident that the insulin response was mediated by the opening of $\mathrm{K}_{\mathrm{ATP}}$ channels. Hence, there was no attenuation of the insulin response (i.e., $\mathrm{K}_{\mathrm{ATP}}$ channel activation) in NPY/AgRP neurons from DIO proestrous females, which would indicate that there is a sex difference in the development of insulin resistance by NPY/AgRP neurons in obesity.

\section{$17 \beta-E_{2}$ Protects NPY/AgRP Neurons against Insulin \\ Resistance}

To explore the role of the gonadal steroids in preserving the insulin response in DIO females, we OVX another cohort of female $N p y^{G F P}$ mice that had been maintained on an HFD for 10 weeks. One week following ovariectomy, we gave one group $(n=5)$ an EB treatment regimen that yielded proestrous serum levels of $E_{2}$ [37] and treated the other group with the oil vehicle $(n=3)$. In contrast to insulin response in OVX females $(n=3)$ fed a control diet in which there was a significant insulin-mediated current (14.1 \pm 2.7 pA, $n=7$ neurons; Fig. 4a, d), NPY/AgRP neurons from OVX, DIO females were completely refractory to the effects of insulin (i.e., there was essentially no outward current, $1.4 \pm 0.9 \mathrm{pA}, n=9$; Fig. $4 \mathrm{~b}$, d). In contrast, NPY/AgRP neurons from EB-treated, OVX DIO females maintained their sensitivity to insulin (i.e., insulin induced a robust outward current, 9.6 \pm 2.2 


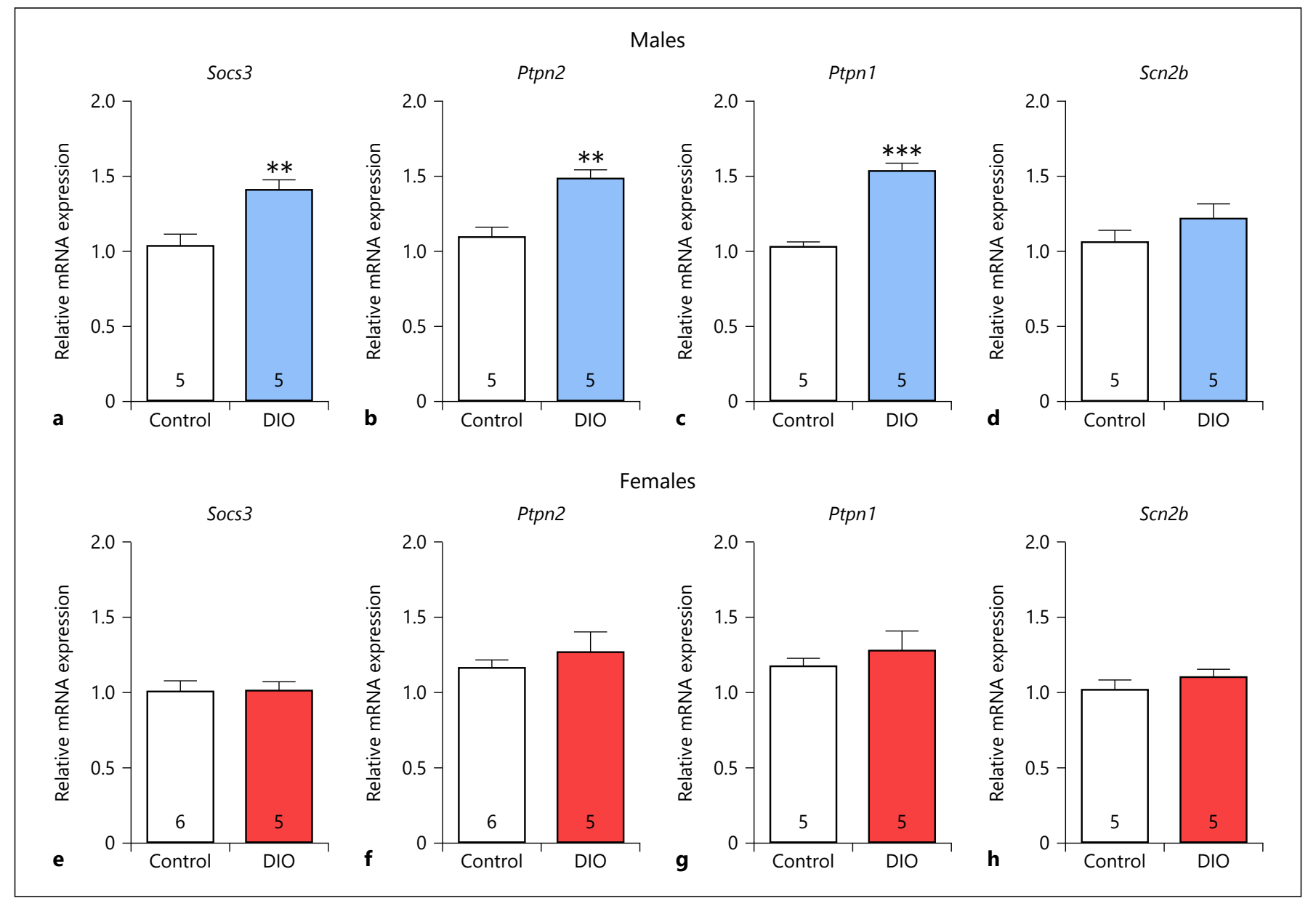

Fig. 5. The mRNA expression levels of Socs3, Ptpn1, and Ptpn2 are upregulated in NPY/AgRP neurons from male DIO mice. a-d HFD consumption led to obesity with corresponding increased mRNA expression of Socs3, Ptpn2, and Ptpn1, but not Scn2b in male NPY/AgRP neurons. Unpaired two-tailed $t$ test for $\mathbf{a}: t_{(8)}=$ 3.682, $p=0.0062$; Unpaired two-tailed $t$ test for $\mathbf{b}: t_{(8)}=4.703, p=$ 0.0015; Unpaired two-tailed $t$ test for c: $t_{(8)}=8.066, p<0.0001$; Unpaired two-tailed $t$ test for $\mathbf{d}$ : $t_{(8)}=1.218, p=0.2362$. e-h None of these genes were significantly increased in NPY/AgRP neurons from OVX + EB treated, DIO females as compared to OVX + EB treated control. Unpaired two-tailed $t$ test for e: $t_{(9)}=0.0930, p=$ 0.9279. Unpaired two-tailed $t$ test for $\mathbf{f}: t_{(9)}=0.7574, p=0.4682$; Unpaired two-tailed $t$ test for $\mathbf{g}: t_{(8)}=0.2648, p=0.7978$; Unpaired two-tailed $t$ test for $\mathbf{h}: t_{(8)}=0.9244, p=0.3823$. Number of animals are indicated. ${ }^{* *} p<0.01$; ${ }^{* * *} p<0.005$. Data points represent mean \pm SEM of relative mRNA expression. DIO, diet-induced obesity; Socs3, suppressor of cytokine signaling-3; Ptpn2, protein tyrosine phosphatase 2; $\operatorname{Scn} 2 b$, sodium channel $\beta 2$ subunit.
pA, $n=12$; Fig. 4c, d). Therefore, in the absence of $E_{2}$, there appears to be an uncoupling of insulin receptor from activating $\mathrm{K}_{\mathrm{ATP}}$ channels in obese females, but the insulin response is rescued with $\mathrm{E}_{2}$ replacement.

\section{SOCS-3, PTP1B and TCPTP Are Differentially Regulated in Obesity}

Leptin upregulates the expression of SOCS-3 in numerous cell types including NPY/AgRP neurons, and SOCS-3 negatively regulates leptin signaling by inhibiting the coupling of the leptin receptor to the Janus kinase

$\mathrm{E}_{2}$ Protects NPY/AgRP Neurons against Insulin Resistance
2 signaling pathway and may also negatively regulate insulin signaling [43]. Indeed, mice fed a high fat diet develop glucose intolerance, which is markedly improved by inactivating the Socs3 gene in POMC neurons [44]. Since we previously found that a high fat diet upregulates Socs 3 mRNA expression in POMC neurons [11], we hypothesized that Socs 3 mRNA expression may be upregulated in NPY/AgRP neurons from insulin-resistant, DIO males but not in insulin-responsive, DIO females. In addition, recent experimental evidence has also implicated tyrosine phosphatases, particularly TCPTP, in regulating 


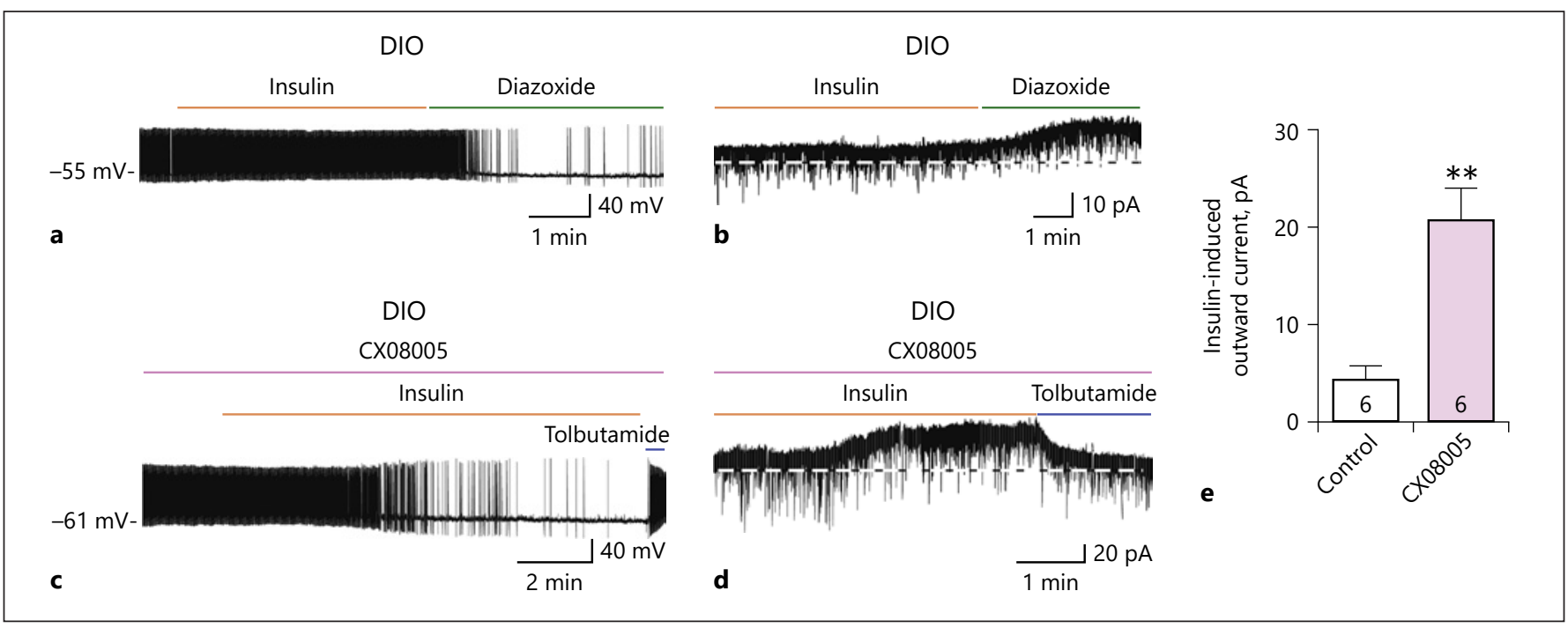

Fig. 6. Insulin-sensitizing effect of CX08005 in NPY/AgRP neurons from male DIO mice. a, b Insulin (20 nM) did not hyperpolarize and reduce firing in current clamp (a) and induce an outward current in voltage clamp (b), but the $\mathrm{K}_{\mathrm{ATP}}$ channel opener diazoxide $(300 \mu \mathrm{M})$ hyperpolarized and induced an outward current in NPY/AgRP neurons from male DIO mice. c, d However, after the arcuate slices from DIO males were pretreated with the PTP1B/TCPTP inhibitor CX08055 at $20 \mu \mathrm{M}$ (treated for $4 \mathrm{~h}$ at $32^{\circ} \mathrm{C}$ ), insulin was fully efficacious to hyperpolarize and inhibit the firing (c) and induce an outward current (d) in NPY/AgRP neu-

leptin and insulin signaling in POMC and NPY/AgRP neurons (see [45] for review). Specifically, TCPTP dephosphorylates tyrosine-phosphorylated substrates such as the insulin receptor to antagonize insulin signaling. Therefore, there were compelling reasons to measure both Socs 3 and Ptpn 2 mRNA expression in the NPY/ AgRP neurons, since both would severely impede insulin signaling in the obese state. Both male and female mice were fed control grain-based diet or high-fat diet as described above and after 10 weeks $N P Y^{G F P}$ neurons were dispersed and harvested as previously described [11], and Socs 3 and Ptpn 2 were measured using quantitative PCR (see Methods). As predicted, both Socs 3 and Ptpn 2 mRNA expression were increased by approximately $40 \%$ in NPY/ AgRP neurons from DIO males as compared to the control diet-fed males (Fig. 5a, b). In contrast, neither Socs 3 nor Ptpn 2 mRNA expression were significantly altered in NPY/AgRP neurons from EB-treated, OVX DIO females as compared to EB-treated control females (Fig. 5e, f), indicating that EB prevented the increase in both Socs 3 and Ptpn 2 mRNA expression with DIO, thereby maintaining insulin signaling in female NPY/AgRP neurons. Based on conditional deletion of PI3K p110 $\beta$ and/or p110 $\alpha$ cata- rons, and both were antagonized by the $\mathrm{K}_{\mathrm{ATP}}$ channel blocker tolbutamide $(100 \mu \mathrm{M})$. $\mathrm{V}_{\text {hold }}=-60 \mathrm{mV}$. e Bar graphs summarizing the insulin-induced currents of NPY/AgRP neurons in control or CX08005 treated arcuate slices from male DIO mice. Data points represent the mean \pm SEM. Unpaired $t$ test for $\mathbf{d}$ versus $\mathbf{b}: t_{(10)}=$ $4.518, p=0.0011 ;{ }^{* *} p<0.01$. Cell numbers are indicated. In current clamp, CX08055 also increased the insulin-induced hyperpolarization (CX08055 treated group: $-10.0 \pm 0.6 \mathrm{mV}, n=2$ vs. controls: $-1.2 \pm 0.5 \mathrm{mV}, n=4)$. DIO, diet-induced obesity.

lytic subunits in NPY/AgRP neurons of male mice, the PI3K signaling pathway has been shown to play a critical role in NPY/AgRP neuronal regulation of energy balance and glucose homeostasis [21, 46]. Therefore, we measured PI3K p110ß (Pi3kcb) transcripts in control and DIO males and found no difference in the mRNA expression between the 2 groups (control diet mRNA relative expression: $1.12 \pm 0.14, n=5$; DIO mRNA relative expression: $1.18 \pm 0.10, n=6$ ), indicating that the PI3K pathway was functioning normally. A recent publication has also implicated Ptpn1 in attenuating insulin signaling in NPY/ AgRP neurons in hyperleptinemic states [47] and as such, we measured this phosphatase expression in both males and females. Indeed, Ptpn 1 mRNA expression was increased by $\sim 50 \%$ in DIO males but not in DIO, EB-treated, OVX females (Fig. 5c, g). As a "negative" transcript control, we also measure Scn $2 b$ mRNA, which we have published is regulated by $\mathrm{E}_{2}$ in kisspeptin neurons [39], and found that the channel subunit expression was unaltered in both DIO males and females versus their control diet-fed counterparts (Fig. 5d, h). As proof of principle, we prepared slices from DIO males after 10 weeks on their diet and pre-incubated the slices in vehicle or the mixed 
PTP1B/TCPTP inhibitor CX08005 (20 $\mu \mathrm{M}$ for $4 \mathrm{~h})$, respectively [48], and then NPYGFP neurons were patched and tested for their response to bath perfused insulin. To our surprise not only was insulin effective, but it was fully efficacious to hyperpolarize and inhibit firing of NPY/ AgRP neurons versus the non-treated slices, and the effects were fully reversed by $\mathrm{K}_{\mathrm{ATP}}$ channel blocker tolbutamide (Fig. 6c, d vs. a, b, summarized in e). Therefore, the phosphatase activity appears to be a molecular switch for dictating the insulin response in DIO males, and EBtreated females are protected against changes in PTP1B/ TCPTP expression with DIO.

\section{Discussion}

Although obesity produces dramatic alterations in metabolic phenotype in both males and females, $E_{2}$ was able to protect females from the development of hypothalamic insulin resistance. Insulin was fully efficacious to activate $\mathrm{K}_{\mathrm{ATP}}$ channels and hyperpolarize NPY/AgRP neurons in DIO, proestrous and EB-treated, OVX females but not in DIO, OVX female or in male mice. Treating OVX females with an $\mathrm{E}_{2}$ regime that mimicked proestrous serum levels of $E_{2}$ fully restored the electrophysiological response to insulin in NPY/AgRP neurons. Also, $\mathrm{E}_{2}$ prevented the increase in Socs3, Ptpn1 and Ptpn2 mRNA expression with DIO, all of which are known to inhibit the coupling of the insulin receptor with its downstream signaling cascades $[44,45,49]$. Therefore, the present studies have identified a sex difference in the development of insulin resistance in NPY/AgRP neurons that involves insulin receptor uncoupling from downstream signaling cascades that ultimately activate $\mathrm{K}_{\mathrm{ATP}}$ channels in these orexigenic hypothalamic neurons.

In obese males but not in obese females the mRNA expression of Socs3, Ptpn1, and Ptpn2 increased by $40-50 \%$ in NPY/AgRP neurons, rendering males but not the females refractory to the effects of insulin; and in our guinea pig model of obesity, males but not females were resistant to the effects of icv insulin [38]. SOCS-3 is known to inhibit the tyrosine kinase activity of the insulin receptor and its interaction with insulin receptor substrate (IRS) proteins; SOCS-3 also targets IRS proteins toward degradation in fat and liver cells [43]. Therefore, the inhibition of InsR interaction with IRS proteins by SOCS-3 and the dephosphorylation of InsR by PTP1B and TCPTP would greatly diminish all downstream signaling, not the least of which is $\mathrm{K}_{\mathrm{ATP}}$ channel opening, in agreement with the findings from Dodd et al. [26, 27]. The sex-specific in- crease in Socs3, Ptpn1, and Ptpn2 mRNA expression with DIO would explain the selective insulin resistance in male versus female NPY/AgRP neurons. By attenuating Socs3, $P t p n 1$, and Ptpn 2 expression in DIO females, $\mathrm{E}_{2}$ preserved the ability of insulin to hyperpolarize NPY/AgRP neurons via $K_{A T P}$ channel opening. $E_{2}$ also maintains the efficacy of insulin to depolarize and excite POMC neurons in DIO females, which complements the anorexigenic actions of $E_{2}$ in NPY/AgRP neurons [11]. Likewise, a recent paper from Dodd et al. [50] has shown that TCPTP plays a critical role in governing the response of POMC neurons to the excitatory effects of insulin such that the phosphatase activity attenuates the insulin response in DIO males. A more recent publication has also implicated PTP1B (Ptpn1) in attenuating insulin signaling in NPY/ AgRP neurons in hyperleptinemia states [47], and indeed Ptpn1 mRNA expression was upregulated in DIO males but not DIO females. As proof of principle, we found that using the non-selective phosphatase inhibitor CX08005 rescued the insulin response in NPY/AgRP neurons from DIO males. Therefore, there is potentially a triad of "negative" molecular regulators (Socs3, Ptpn1, Ptpn2) of insulin receptor coupling in obese states, but inhibiting the phosphatase activity (PTP1B and TCPTP) appears to be sufficient to restore the insulin response in DIO males (current findings).

In obese male mice, hypothalamic levels of Ptpn2 mRNA and TCPTP are high and remain elevated even after feeding (present results and [26, 51]), and the resultant sustained repression of insulin receptor signaling in NPY/AgRP neurons most probably contributes to the elevated hepatic glucose production and hyperglycemia characteristic of the obese and insulin-resistant state. Feeding- and fasting-associated fluctuations of TCPTP protein in NPY/AgRP neurons help coordinate hepatic glucose production such that $i c v$ insulin is ineffective to alter hepatic function in food-restricted control male mice, whose hypothalamic TCPTP levels are elevated [26]. However, Ptpn 2 deletion in NPY/AgRP neurons can reinstate the response to $i c v$ insulin. Enhancement of insulin inhibition of NPY/AgRP neurons by Ptpn2 deletion in males also improves glucose metabolism through the promotion of brown and beige adipose tissue glucose uptake $[26,52]$. In fed/satiated male mice in which TCPTP is downregulated, the resultant enhancement of insulin signaling and resultant inhibition of NPY/AgRP neurons increases sympathetic activity and browning of white adipose tissue to promote the expenditure of energy. Therefore, the results from multiple labs $[9,16-18,26,27]$ support a critical role of insulin signaling in NPY/AgRP neu- 
rons to coordinate hepatic glucose production with whole body metabolism to prevent hypoglycemia in fasted states. However, more studies are needed in female mice to determine whether there are sex differences in control of hepatic glucose production.

We can state with some certainty that circulating estrogens are responsible for the sex difference in protecting females against insulin resistance in the obese state since we restored insulin signaling in OVX females with EB replacement therapy (present findings and [11]). An obvious question is - what is the mechanism(s) by which $\mathrm{E}_{2}$ protects hypothalamic neurons against insulin resistance? Complementary to its physiological actions in NPY/AgRP neurons, the anorexigenic hormone $\mathrm{E}_{2}$ also protects female POMC neurons against insulin resistance in the obese state. In POMC neurons however, insulin (and leptin) activate TRPC5 channels, and $\mathrm{E}_{2}$ preserves the ability of insulin to activate TRPC5 channels and depolarize POMC neurons in obese female mice [11]. Similar to NPY/AgRP neurons, the insulin response in POMC neurons was abrogated in OVX, DIO females but restored with $\mathrm{E}_{2}$ replacement (i.e., EB treatment). Besides its direct excitatory effects on POMC neurons [53-57], the longer term protective actions of $E_{2}$ in POMC neurons are due to alterations in several key genes [11]. Prominently, $\mathrm{E}_{2}$ upregulates Cav3.1 mRNA expression and the T-type calcium current that collaborates with TRPC5 channels to drive $\mathrm{Ca}^{2+}$ currents in POMC neurons. On the other hand, $\mathrm{E}_{2}$ inhibits the expression of endosomal membrane protein stromal-interaction molecule 1, which is responsible for sequestering TRPC5 channels from plasma membrane receptor activation [11]. Under normal physiological conditions, TRPC5 channel complexes are coupled to plasma membrane receptors (InsR, leptin receptor and $\mathrm{G}$ protein-coupled receptors like serotonin $5 \mathrm{HT}_{2 \mathrm{c}}$ ) in POMC neurons but in stressed states such as with obesity, the TRPC5 channels associate with stromal-interaction molecule 1 and become coupled to calcium store regulation within the endoplasmic reticulum [58]. Moreover similar to NPY/AgRP neurons, $\mathrm{E}_{2}$ prevents the increase in SOCS-3 (Socs3 mRNA) expression in POMC neurons of DIO females. Most of these transcriptional effects of $\mathrm{E}_{2}$ in POMC neurons are thought to be mediated by an estrogen receptor $\alpha(E R \alpha)$ dependent mechanism, since ovariectomy leads to hyperphagia [59-61], which is recapitulated by selective deletion of ERa in POMC neurons [62]. However, NPY/AgRP neurons are not thought to express the transcription factors ER $\alpha$ and ER $\beta$ [63], although we have documented the mRNA expression of ERa in NPY/AgRP neurons [64]. In addition, we have discovered that there are other non-classical estrogenic signaling mechanisms in NPY/AgRP neurons [35], and we have identified a number of channels and signaling molecules that are upregulated by $\mathrm{E}_{2}$ treatment. Prominent among the channels is KCNQ5, which underlies the sub-threshold inhibitory M-current $[64,65]$. We have also documented non-canonical membrane-associated ER $\alpha$ and Gq-coupled membrane-associated estrogen receptor (GqMER) signaling pathways in NPY/ AgRP neurons [35]. Selective activation of GqMER by STX rapidly inhibits NPY/AgRP neurons, which correlates with the reduced food intake and weight gain in STX-treated, gonadectomized mice and guinea pigs $[35,57]$; and long-term treatment (4 weeks) with STX downregulates the expression of NPY, which correlates with its inhibitory actions on feeding and weight gain after ovariectomy $[57,66]$.

Besides the pronounced effects of non-canonical $E_{2}$ signaling on the endogenous excitability of NPY/AgRP neurons, the steroid hormone $\mathrm{E}_{2}$ also augments inhibitory synaptic input, specifically the inhibitory glutamatergic (mGluR7-mediated) input from kisspeptin neurons [38] and $\mu$-opioid input from POMC neurons [67]. Furthermore, STX enhances $\mathrm{Ga}_{\mathrm{i}, \mathrm{o}}$-coupled receptor (e.g., $\mathrm{GABA}_{\mathrm{B}}$, mGluR7 and $\mu$-opioid)-mediated activation of $\mathrm{G}$ protein-coupled inwardly rectifying $\mathrm{K}^{+}$channels [35]. Therefore, $\mathrm{E}_{2}$ inhibits NPY/AgRP neurons using multiple signaling pathways to preserve insulin signaling under physiological and pathophysiological (i.e., obesity) conditions, which underscores the physiological importance of this gonadal steroid. Although testosterone is aromatized to $\mathrm{E}_{2}$ in the hypothalamus [68], there appears not to be enough conversion of testosterone to preserve insulin signaling in the obese male. However, we have found that similar to females the selective GqMER ligand STX can reduce food intake and weight gain in males [35], which argues for an estrogenic protective signaling pathway in the NPY/AgRP neurons in males. Future experiments need to address this possibility, but clearly our results have identified a vital role for $\mathrm{E}_{2}$ in preserving insulin receptor coupling to channel activation in NPY/AgRP and POMC neurons and thus protect against the development of insulin resistance in obese females.

\section{Disclosure Statement}

The authors declare that they have no conflicts of interest to disclose. 


\section{Funding Sources}

This work was supported by US National Institutes of Health Grants NS038809 to M.J.K., NS043330 to O.K.R., and DK068098 to M.J.K. and O.K.R.

\section{Author Contributions}

J.Q. and C.Z. performed and analyzed the electrophysiology experiments. M.A.B. did the single-cell harvesting and quantitative PCR analysis of the harvested cells. M.J.K., O.K.R., and J.Q. designed the experiments, analyzed the data, and wrote the manuscript. We thank Ashley M. Connors and Uyen-Vy Navarro for technical assistance with mouse body weight and body composition measurements.

\section{References}

1 Gao Q, Horvath TL. Neurobiology of feeding and energy expenditure. Annu Rev Neurosci. 2007;30(1):367-98

2 Chen Y, Knight ZA. Making sense of the sensory regulation of hunger neurons. BioEssays. 2016 Apr;38(4):316-24.

3 Aponte Y, Atasoy D, Sternson SM. AGRP neurons are sufficient to orchestrate feeding behavior rapidly and without training. Nat Neurosci. 2011 Mar;14(3):351-5.

4 Krashes MJ, Koda S, Ye C, Rogan SC, Adams AC, Cusher DS, et al. Rapid, reversible activation of AgRP neurons drives feeding behavior in mice. J Clin Invest. 2011 Apr;121(4):14248.

5 Wei Q, Krolewski DM, Moore S, Kumar V, Li $\mathrm{F}$, Martin B, et al. Uneven balance of power between hypothalamic peptidergic neurons in the control of feeding. Proc Natl Acad Sci USA. 2018 Oct;115(40):E9489-98.

6 Schwartz MW, Woods SC, Porte D Jr, Seeley RJ, Baskin DG. Central nervous system control of food intake. Nature. 2000 Apr; 404(6778):661-71.

7 Morton GJ, Cummings DE, Baskin DG, Barsh GS, Schwartz MW. Central nervous system control of food intake and body weight. Nature. 2006 Sep;443(7109):289-95.

8 Belgardt BF, Brüning JC. CNS leptin and insulin action in the control of energy homeostasis. Ann N Y Acad Sci. 2010 Nov;1212(1): 97-113.

9 Qiu J, Zhang C, Borgquist A, Nestor CC, Smith AW, Bosch MA, et al. Insulin excites anorexigenic proopiomelanocortin neurons via activation of canonical transient receptor potential channels. Cell Metab. 2014 Apr; 19(4):682-93.

10 Ruud J, Steculorum SM, Brüning JC. Neuronal control of peripheral insulin sensitivity and glucose metabolism. Nat Commun. 2017 May;8(1):15259.

11 Qiu J, Bosch MA, Meza C, Navarro UV, Nestor CC, Wagner EJ, et al. Estradiol protects proopiomelanocortin neurons against insulin resistance. Endocrinology. 2018 Feb; 159(2):647-64.

12 Benoit SC, Air EL, Coolen LM, Strauss R, Jackman A, Clegg DJ, et al. The catabolic action of insulin in the brain is mediated by melanocortins. J Neurosci. 2002 Oct;22(20): 9048-52.
13 Brown LM, Clegg DJ, Benoit SC, Woods SC. Intraventricular insulin and leptin reduce food intake and body weight in C57BL/6J mice. Physiol Behav. 2006 Dec;89(5):687-91.

14 Clegg DJ, Gotoh K, Kemp C, Wortman MD, Benoit SC, Brown LM, et al. Consumption of a high-fat diet induces central insulin resistance independent of adiposity. Physiol Behav. 2011 Apr;103(1):10-6.

15 Obici S, Zhang BB, Karkanias G, Rossetti L. Hypothalamic insulin signaling is required for inhibition of glucose production. Nat Med. 2002 Dec;8(12):1376-82.

16 Könner AC, Janoschek R, Plum L, Jordan SD, Rother E, Ma X, et al. Insulin action in AgRPexpressing neurons is required for suppression of hepatic glucose production. Cell Metab. 2007 Jun;5(6):438-49.

17 Lin HV, Plum L, Ono H, Gutiérrez-Juárez R, Shanabrough M, Borok E, et al. Divergent regulation of energy expenditure and hepatic glucose production by insulin receptor in agouti-related protein and POMC neurons. Diabetes. 2010 Feb;59(2):337-46.

18 Scherer T, O'Hare J, Diggs-Andrews K, Schweiger M, Cheng B, Lindtner C, et al. Brain insulin controls adipose tissue lipolysis and lipogenesis. Cell Metab. 2011 Feb;13(2): 183-94.

19 Spanswick D, Smith MA, Mirshamsi S, Routh $\mathrm{VH}$, Ashford ML. Insulin activates ATP-sensitive $\mathrm{K}+$ channels in hypothalamic neurons of lean, but not obese rats. Nat Neurosci. 2000 Aug;3(8):757-8.

20 Plum L, Rother E, Münzberg H, Wunderlich FT, Morgan DA, Hampel B, et al. Enhanced leptin-stimulated Pi3k activation in the CNS promotes white adipose tissue transdifferentiation. Cell Metab. 2007 Dec;6(6):431-45.

21 Huang Y, He Z, Gao Y, Lieu L, Yao T, Sun J, et al. Phosphoinositide 3-kinase is integral for the acute activity of leptin and insulin in male arcuate NPY/AgRP neurons. J Endocr Soc. 2018 Apr;2(6):518-32.

22 Rameh LE, Rhee SG, Spokes K, Kazlauskas A, Cantley LC, Cantley LG. Phosphoinositide 3-kinase regulates phospholipase $\mathrm{C} \gamma$ mediated calcium signaling. J Biol Chem. 1998 Sep;273(37):23750-7.
23 Falasca M, Logan SK, Lehto VP, Baccante G, Lemmon MA, Schlessinger J. Activation of phospholipase $\mathrm{C} \gamma$ by PI 3-kinase-induced $\mathrm{PH}$ domain-mediated membrane targeting. EMBO J. 1998 Jan;17(2):414-22.

24 Bae YS, Cantley LG, Chen CS, Kim SR, Kwon KS, Rhee SG. Activation of phospholipase C- $\gamma$ by phosphatidylinositol 3,4,5-trisphosphate. J Biol Chem. 1998 Feb;273(8):4465-9.

25 Shyng SL, Nichols CG. Membrane phospholipid control of nucleotide sensitivity of KATP channels. Science. 1998 Nov;282(5391):1138-41.

26 Dodd GT, Andrews ZB, Simonds SE, Michael NJ, DeVeer M, Brüning JC, et al. A hypothalamic phosphatase switch coordinates energy expenditure with feeding. Cell Metab. 2017 Sep;26(3):577.

27 Dodd GT, Lee-Young RS, Brüning JC, Tiganis T. TCPTP regulates insulin signaling in AgRP neurons to coordinate glucose metabolism with feeding. Diabetes. 2018 Jul;67(7): 1246-57.

28 Pocai A, Lam TK, Gutierrez-Juarez R, Obici S, Schwartz GJ, Bryan J, et al. Hypothalamic K(ATP) channels control hepatic glucose production. Nature. 2005 Apr;434(7036): 1026-31.

29 Kim B, Feldman EL. Insulin resistance in the nervous system. Trends Endocrinol Metab. 2012 Mar;23(3):133-41.

30 Janssen I, Powell LH, Crawford S, Lasley B, Sutton-Tyrrell K. Menopause and the metabolic syndrome: the Study of Women's Health Across the Nation. Arch Intern Med. 2008 Jul; 168(14):1568-75.

31 Gustafsson PE, Persson M, Hammarström A. Life course origins of the metabolic syndrome in middle-aged women and men: the role of socioeconomic status and metabolic risk factors in adolescence and early adulthood. Ann Epidemiol. 2011 Feb;21(2):103-10.

32 van den Pol AN, Yao Y, Fu LY, Foo K, Huang $\mathrm{H}$, Coppari R, et al. Neuromedin B and gastrin-releasing peptide excite arcuate nucleus neuropeptide $Y$ neurons in a novel transgenic mouse expressing strong Renilla green fluorescent protein in NPY neurons. J Neurosci. 2009 Apr;29(14):4622-39.

33 Parton LE, Ye CP, Coppari R, Enriori PJ, Choi $\mathrm{B}$, Zhang CY, et al. Glucose sensing by POMC neurons regulates glucose homeostasis and is impaired in obesity. Nature. 2007 Sep; 449(7159):228-32. 
34 Paeger L, Pippow A, Hess S, Paehler M, Klein AC, Husch A, et al. Energy imbalance alters $\mathrm{Ca} 2+$ handling and excitability of POMC neurons. Elife. 2017 Aug;6:e25641.

35 Smith AW, Bosch MA, Wagner EJ, Rønnekleiv OK, Kelly MJ. The membrane estrogen receptor ligand STX rapidly enhances GABAergic signaling in NPY/AgRP neurons: role in mediating the anorexigenic effects of 17ß-estradiol. Am J Physiol Endocrinol Metab. 2013 Sep;305(5):E632-40.

36 Zhang C, Tonsfeldt KJ, Qiu J, Bosch MA, Kobayashi K, Steiner RA, et al. Molecular mechanisms that drive estradiol-dependent burst firing of Kiss1 neurons in the rostral periventricular preoptic area. Am J Physiol Endocrinol Metab. 2013 Dec;305(11):E1384-97.

37 Bosch MA, Tonsfeldt KJ, Rønnekleiv OK. mRNA expression of ion channels in $\mathrm{GnRH}$ neurons: subtype-specific regulation by 17ß-estradiol. Mol Cell Endocrinol. 2013 Mar;367(1-2):85-97.

38 Qiu J, Rivera HM, Bosch MA, Padilla SL, Stincic TL, Palmiter RD, et al. Estrogenic-dependent glutamatergic neurotransmission from kisspeptin neurons governs feeding circuits in females. Elife. 2018 Aug; 7:e35656.

39 Zhang C, Bosch MA, Qiu J, Rønnekleiv OK, Kelly MJ. 17 $\beta$-Estradiol increases persistent $\mathrm{Na}(+)$ current and excitability of AVPV/PeN Kiss1 neurons in female mice. Mol Endocrinol. 2015 Apr;29(4):518-27.

40 Pfaffl MW. A new mathematical model for relative quantification in real-time RT-PCR. Nucleic Acids Res. 2001 May;29(9):e45.

41 Schmittgen TD, Livak KJ. Analyzing realtime PCR data by the comparative $\mathrm{C}(\mathrm{T})$ method. Nat Protoc. 2008;3(6):1101-8.

42 Ashcroft FM, Gribble FM. New windows on the mechanism of action of K(ATP) channel openers. Trends Pharmacol Sci. 2000 Nov; 21(11):439-45.

43 Howard JK, Flier JS. Attenuation of leptin and insulin signaling by SOCS proteins. Trends Endocrinol Metab. 2006 Nov;17(9):365-71.

44 Kievit P, Howard JK, Badman MK, Balthasar $\mathrm{N}$, Coppari R, Mori H, et al. Enhanced leptin sensitivity and improved glucose homeostasis in mice lacking suppressor of cytokine signaling-3 in POMC-expressing cells. Cell Metab. 2006 Aug;4(2):123-32.

45 Zhang ZY, Dodd GT, Tiganis T. Protein tyrosine phosphatases in hypothalamic insulin and leptin signaling. Trends Pharmacol Sci. 2015 Oct;36(10):661-74
46 Al-Qassab H, Smith MA, Irvine EE, Guillermet-Guibert J, Claret M, Choudhury AI, et al. Dominant role of the $\mathrm{p} 110 \beta$ isoform of PI3K over p110a in energy homeostasis regulation by POMC and AgRP neurons. Cell Metab. 2009 Nov; 10(5):343-54.

47 Balland E, Chen W, Dodd GT, Conductier G, Coppari R, Tiganis $\mathrm{T}$, et al. Leptin signaling in the arcuate nucleus reduces insulin's capacity to suppress hepatic glucose production in obese mice. Cell Rep. 2019 Jan;26(2):346-355.e3.

48 Zhang X, Tian J, Li J, Huang L, Wu S, Liang $\mathrm{W}$, et al. A novel protein tyrosine phosphatase $1 \mathrm{~B}$ inhibitor with therapeutic potential for insulin resistance. Br J Pharmacol. 2016 Jun; 173(12):1939-49.

49 Pedroso JA, Buonfiglio DC, Cardinali LI, Furigo IC, Ramos-Lobo AM, Tirapegui J, et al. Inactivation of SOCS3 in leptin receptor-expressing cells protects mice from diet-induced insulin resistance but does not prevent obesity. Mol Metab. 2014 Jun;3(6):608-18.

50 Dodd GT, Michael NJ, Lee-Young RS, Mangiafico SP, Pryor JT, Munder AC, et al. Insulin regulates POMC neuronal plasticity to control glucose metabolism. Elife. 2018 Sep; 7:e38704.

51 Loh K, Fukushima A, Zhang X, Galic S, Briggs D, Enriori PJ, et al. Elevated hypothalamic TCPTP in obesity contributes to cellular leptin resistance. Cell Metab. 2011 Nov; 14(5): 684-99.

52 Dodd GT, Decherf S, Loh K, Simonds SE, Wiede F, Balland E, et al. Leptin and insulin act on POMC neurons to promote the browning of white fat. Cell. 2015 Jan;160(1-2):88-104.

53 Kelly MJ, Loose MD, Rønnekleiv OK. Estrogen suppresses mu-opioid- and GABAB-mediated hyperpolarization of hypothalamic arcuate neurons. J Neurosci. 1992 Jul;12(7): 2745-50.

54 Lagrange AH, Rønnekleiv OK, Kelly MJ. The potency of mu-opioid hyperpolarization of hypothalamic arcuate neurons is rapidly attenuated by $17 \beta$-estradiol. J Neurosci. 1994 Oct;14(10):6196-204.

55 Lagrange AH, Rønnekleiv OK, Kelly MJ. Modulation of $\mathrm{G}$ protein-coupled receptors by an estrogen receptor that activates protein kinase A. Mol Pharmacol. 1997 Apr;51(4): 605-12.

56 Qiu J, Bosch MA, Tobias SC, Grandy DK, Scanlan TS, Rønnekleiv OK, et al. Rapid signaling of estrogen in hypothalamic neurons involves a novel G-protein-coupled estrogen receptor that activates protein kinase C. J Neurosci. 2003 Oct;23(29):9529-40.

57 Qiu J, Bosch MA, Tobias SC, Krust A, Graham SM, Murphy SJ, et al. A G-protein-coupled estrogen receptor is involved in hypothalamic control of energy homeostasis. J Neurosci. 2006 May;26(21):5649-55.

58 Arruda AP, Pers BM, Parlakgul G, Güney E, Goh T, Cagampan E, et al. Defective STIMmediated store operated $\mathrm{Ca} 2+$ entry in hepatocytes leads to metabolic dysfunction in obesity. Elife. 2017 Dec;6:e29968.

59 Ahdieh HB, Wade GN. Effects of hysterectomy on sexual receptivity, food intake, running wheel activity, and hypothalamic estrogen and progestin receptors in rats. J Comp Physiol Psychol. 1982 Dec;96(6):886-92.

60 Geary N. Estradiol and the control of eating. Appetite. 1997 Dec;29(3):386

61 Eckel LA. Estradiol: a rhythmic, inhibitory, indirect control of meal size. Physiol Behav. 2004 Aug;82(1):35-41.

$62 \mathrm{Xu}$ Y, Nedungadi TP, Zhu L, Sobhani N, Irani BG, Davis KE, et al. Distinct hypothalamic neurons mediate estrogenic effects on energy homeostasis and reproduction. Cell Metab. 2011 Oct;14(4):453-65.

63 Olofsson LE, Pierce AA, Xu AW. Functional requirement of AgRP and NPY neurons in ovarian cycle-dependent regulation of food intake. Proc Natl Acad Sci USA. 2009 Sep; 106(37):15932-7.

64 Roepke TA, Qiu J, Smith AW, Rønnekleiv OK, Kelly MJ. Fasting and $17 \beta$-estradiol differentially modulate the $\mathrm{M}$-current in neuropeptide Y neurons. J Neurosci. 2011 Aug; 31(33):11825-35.

65 Roepke TA, Malyala A, Bosch MA, Kelly MJ, Rønnekleiv OK. Estrogen regulation of genes important for $\mathrm{K}+$ channel signaling in the arcuate nucleus. Endocrinology. 2007 Oct; 148(10):4937-51.

66 Roepke TA, Xue C, Bosch MA, Scanlan TS, Kelly MJ, Rønnekleiv OK. Genes associated with membrane-initiated signaling of estrogen and energy homeostasis. Endocrinology. 2008 Dec;149(12):6113-24.

67 Stincic TL, Rønnekleiv OK, Kelly MJ. Diverse actions of estradiol on anorexigenic and orexigenic hypothalamic arcuate neurons. Horm Behav. 2018 Aug; 104:146-55.

68 Roselli CE, Resko JA. The distribution and regulation of aromatase activity in the central nervous system. Steroids. 1987 Oct-Dec;50(46):495-508. 